\title{
Polusi Udara Dalam Rumah Terhadap Infeksi Saluran Pernafasan Akut pada Balita di TPA Sukawinatan Palembang
}

\author{
Rahmi Garmini ${ }^{1 *}$, Rachmadhi Purwana ${ }^{2}$ \\ ${ }^{1}$ Program Studi DIII Kesehatan Lingkungan STIKes Muhammadiyah Palembang \\ 2 Departemen Kesehatan Lingkungan, Fakultas Kesehatan Masyarakat, Universitas Indonesia \\ *Corresponding author: rahmi.garmini@gmail.com
}

Info Artikel : Diterima 28 November 2018 ; Disetujui 11 November 2019 ; Publikasi 1 April 2020

\begin{abstract}
ABSTRAK
Latar belakang: Infeksi Saluran Pernapasan Akut (ISPA) merupakan penyebab utama morbiditas dan mortalitas pada bayi dan anak-anak. ISPA bisa terjadi karena pencemaran kualitas udara di luar maupun di dalam ruangan. Salah satunya gas sulfur dioksida (SO2) yang ada di tempat pembuangan sampah dapat mengganggu sistem pernapasan pada balita. Balita lebih berisiko tertular ISPA karena kekebalan tubuh yang dialami balita belum terbentuk sempurna. Penelitian ini bertujuan untuk mengetahui kondisi udara dalam rumah dan karakteristik balita terhadap kejadian ISPA pada balita di sekitar Tempat Pembuangan Akhir Sampah Sukawinatan Kelurahan Sukajaya Palembang.

Metode: Jenis penelitian analitik, desain penelitian cross sectional. Variabel terukur adalah kondisi udara dalam rumah, karakteristik balita, dan kejadian ISPA pada balita. Populasi penelitian adalah anak balita berumur 12-59 bulan yang bertempat tinggal di Kelurahan Sukajaya dan sampel berjumlah 94 orang. Data dianalisis dengan uji chi-square, $t$-test independent, dan regresi logistik.

Hasil: Period Prevalence kejadian ISPA pada balita sebesar 59,6\%. Variabel penggunaan obat anti nyamuk, perokok dalam rumah, ventilasi, status gizi dan status imunisasi secara statistik menunjukkan hubungan yang bermakna terhadap kejadian ISPA pada balita, sedangkan variabel kadar SO2 dalam rumah dan umur balita secara statistik tidak menunjukkan hubungan yang bermakna terhadap kejadian ISPA pada balita. Hasil analisis multivariat diperoleh bahwa variabel ventilasi rumah merupakan variabel yang paling dominan berhubungan dengan kejadian ISPA pada balita.
\end{abstract}

Simpulan: Ventilasi dapat menjadi faktor risiko terhadap terjadinya ISPA, karena ventilasi mempunyai fungsi sebagai sarana sirkulasi udara sehingga dapat mengurangi pencemaran udara dalam rumah.

Kata kunci: ISPA; Sulfur dioksida; Ventilasi

\section{ABSTRACT}

Title: Indoor Air Pollution And Acute Respiratory Infection In Child Under Five Years In Sukawinatan Landfills Palembang.

Background: Acute Respiratory Infections (ARI) is a major cause of morbidity and mortality in young children. ARI can occurs because indoor and outdoor air pollution. One of them is gas sulfur dioxide (SO2) in landfills that it can be irritate the respiratory tract in young children. Young children have higher risk of contracting ARI because the immune of young children not yet fully formed. This research aims to find out Indoor air Pollution and Characteristics of acute respiratory infection in under-fives in Sukawinatan Landfills.

Methods: Type of research was analitic, cross-sectional study design. Measurement of indoor air pollution, characteristics of young children, and prevalence of acute respiratory infection. The population of this research was young children aged 12-59 months who lived in Kelurahan Sukajaya and 94 samples. Data were analyzed by chi-square, t-test independent, and logistic regression.

Results: Period Prevalence of acute respiratory infection in young children about 59,6\%. Using mosquito repellent, smokers in the house, ventilation, nutrition and immunization status were significant correlation to acute respiratory infection in young children. While SO2 levels in the home and age of young children were 
insignificant correlation to acute respiratory infection in young children. Multivariate analysis showed that the variables of ventilation with SO2 levels were the most dominant variable related to acute respiratory infection in young children.

Conclusion: One of risk factor of acute respiratory infection is ventilation, because its function as air circulation to reduce indoor air pollution.

Keywords: Acute Respiratory Infections; Sulfur Dioxide; Ventilation

\section{PENDAHULUAN}

Infeksi Saluran Pernapasan Akut (ISPA) merupakan penyakit saluran pernapasan atas atau bawah yang termasuk penyakit golongan Air Borne Disease atau yang ditularkan melalui udara dengan inhalasi yang dapat menimbulkan berbagai spektrum penyakit yang berkisar dari penyakit tanpa gejala atau infeksi ringan sampai penyakit yang parah dan mematikan, tergantung pada patogen penyebabnya, faktor lingkungan, dan faktor pejamu. ${ }^{1}$

ISPA merupakan penyebab utama morbiditas dan mortalitas penyakit menular di dunia. Hampir empat juta orang meninggal akibat ISPA setiap tahun dan $98 \%$ nya disebabkan oleh infeksi saluran pernapasan bawah. Tingkat mortalitas sangat tinggi pada bayi, anak-anak dan orang lanjut usia terutama di negara-negara dengan pendapatan per kapita rendah dan menengah. Begitu juga ISPA, merupakan salah satu penyebab utama konsultasi atau rawat inap di fasilitas pelayanan kesehatan terutama pada bagian perawatan anak. ${ }^{1}$

Penyakit infeksi saluran pernapasan akut, khususnya pneumonia masih menjadi penyebab kematian terbesar bayi dan balita, lebih banyak dibanding dengan gabungan penyakit AIDS, malaria dan campak. Badan kesehatan dunia (WHO) menyebut sebagai "the forgotten killer of children". Pneumonia merupakan penyakit menular penyebab kematian nomor satu pada balita di dunia. Pnumonia menyumbang $16 \%$ dari seluruh kematian anak di bawah 5 tahun, menyebabkan kematian pada 920.136 balita atau lebih dari 2.500 per hari pada tahun 2015 .

Insidens menurut kelompok umur balita diperkirakan 0,29 kasus per anak/tahun di negara berkembang dan 0,05 kasus per anak/tahun di negara maju. Ini menunjukkan bahwa terdapat 156 juta kasus baru di dunia per tahun dimana 151 juta kasus $(96,7 \%)$ terjadi di negara berkembang. Kasus terbanyak terjadi di India (43 juta), China (21 juta) dan Pakistan (10 juta) dan Bangladesh, Indonesia, Nigeria masingmasing 6 juta kasus. Dari semua kasus yang terjadi di masyarakat, $7-13 \%$ kasus berat dan memerlukan perawatan rumah sakit. Kasus batuk-pilek pada Balita di Indonesia diperkirakan 2-3 kali per tahun. ${ }^{2}$

Balita lebih berisiko tertular ISPA karena kekebalan tubuh yang dialami oleh balita belum terbentuk sempurna dan penularan atau penyebaran ISPA sangat mudah terjadi melalui batuk dan bersin yang membentuk partikel infeksius di udara yang dapat berpindah dari orang sakit kepada orang yang mempunyai risiko tertular atau dapat melalui kontak langsung. ${ }^{3}$

Di Indonesia, dari hasil SDKI 2012 disebutkan bahwa angka kematian balita adalah sebesar 40 per 1000. Sementara berdasarkan Riskesdas (2007), penyebab kematian bayi terbanyak diare $(31,4 \%)$ dan pnemonia $(23,8 \%)$. Sedangkan penyebab terbanyak kematian anak balita adalah diare $(25,2 \%)$ dan pnemonia $(15,5 \%){ }^{4}$ ISPA merupakan salah satu penyebab utama kunjungan pasien di Puskesmas $(40 \%-60 \%)$ dan rumah sakit (15\%-30\%) (Kemenkes RI, 2012). ${ }^{5}$

Selain itu, faktor risiko yang meningkatkan insidens ISPA pada balita adalah kondisi lingkungan (misalnya, polutan udara, kepadatan anggota keluarga), kelembaban, kebersihan, musim, temperatur); ketersediaan dan efektivitas pelayanan kesehatan dan langkah pencegahan infeksi untuk mencegah penyebaran (misalnya, vaksin, akses terhadap fasilitas pelayanan kesehatan, kapasitas ruang isolasi); faktor pejamu, seperti usia, kebiasaan merokok, kemampuan pejamu menularkan infeksi, status kekebalan, status gizi, infeksi sebelumnya atau infeksi serentak yang disebabkan oleh patogen lain, kondisi kesehatan umum; dan karakteristik patogen, seperti cara penularan, daya tular, faktor virulensi. ${ }^{1}$

Pengolahan sampah di TPAS Sukawinatan menggunakan sistem controlled landfill dapat meningkatkan pencemaran udara. Menurut Dinas Kebersihan Kota Palembang Tahun 2015, jumlah timbunan sampah per hari di Kota Palembang diperkirakan mencapai $500 \mathrm{s.d} \pm 600$ ton/hari, dengan komponen sampah terbanyak dihasilkan oleh limbah sisa makanan dan daun sebanyak $67,5 \%$.

Asap dari pembakaran sampah tersebut salah satunya menghasilkan sulfur dioksida yang merupakan salah satu dari kelompok gas yang sangat reaktif yang dikenal sebagai "oksida belerang". SO2 terkait dengan sejumlah efek buruk pada sistem pernapasan, dan isu-isu lingkungan lainnya. ${ }^{6}$

Berdasarkan penelitian Weli dan Obisesan ${ }^{7}$ mengenai kondisi meteorologi di sekitar TPA dan implikasinya terhadap stagnasi polutan atmosfer di Rumuolumeni, bahwa konsentrasi $\mathrm{SO} 2$ tinggi di lokasi TPA (Tempat Pembuangan Akhir). Jarak dari pusat TPA memengaruhi konsentrasi polutan udara $\mathrm{SO} 2$. Hasil penelitian kadar SO2 di TPA Namo Bintang (Siregar, 2011), ditemukan ternyata kadar sulfur dioksida melebihi syarat baku mutu udara ambien yang ditetapkan oleh PP No. 41 Tahun 1999 
yaitu sebesar 1199,29 $\mu \mathrm{g} / \mathrm{Nm} 3$ dengan syarat baku mutu udara ambien adalah sebesar $\leq 900 \mu \mathrm{g} / \mathrm{Nm} 3$.

Berdasarkan fakta yang telah diuraikan di atas, penelitian ini bertujuan untuk menganalisis polusi udara yang terdapat dalam rumah masyarakat yang tinggal di sekitar tempat pembungan akhir sampah Sukawinatan Palembang.

\section{MATERI DAN METODE}

Jenis penelitian ini adalah penelitian analitik dengan menggunakan desain studi potong lintang (cross sectional). Sampel dalam penelitian ini adalah balita berumur 12-59 bulan yang bertempat tinggal di sekitar kawasan tempat pembuangan akhir sampah Sukawinatan dengan kriteria inklusi dan eksklusi. Pemilihan sampel dilakukan dengan menggunakan metode simple random sampling, artinya seluruh anggota populasi memiliki peluang yang sama besar untuk terpilih sebagai responden dan diperoleh total sampel sebanyak 94 balita. Analisis data penelitian menggunakan uji chi square dan uji t-independent, kemudian dilakukan uji regresi logistik ganda dengan pemodelan chi-square prediksi.

\section{HASIL DAN PEMBAHASAN}

Hasil penelitian bivariat diperoleh bahwa kadar $\mathrm{SO} 2$ dalam rumah berupa data numerik, sehingga untuk mengetahui adanya hubungan kadar SO2 dalam rumah terhadap kejadian ISPA dilakukan dengan uji tindependent (Tabel 1), sedangkan pada tabel 2 menggunakan uji chi-square.

Tabel 1. Hubungan Kadar $\mathrm{SO}_{2}$ Dalam Rumah Terhadap Kejadian ISPA Pada Balita di TPA Sukawinatan Tahun 2017

\begin{tabular}{lccc}
\hline $\begin{array}{c}\text { ISPA Pada } \\
\text { Balita }\end{array}$ & Mean & $\begin{array}{c}\text { Standar } \\
\text { Deviasi }\end{array}$ & p value \\
\hline ISPA & 40,3269 & 0,286 & 0,05 \\
Tidak ISPA & 40,2119 & 0,270 & \\
\hline
\end{tabular}

Tabel 2. Hubungan Penggunaan Obat Anti Nyamuk, Perokok Dalam Rumah, Ventilasi, Umur, Status Gizi, dan Status Imunisasi Terhadap Kejadian ISPA Pada Balita di TPA Sukawinatan Tahun 2017

\begin{tabular}{|c|c|c|c|c|}
\hline \multirow[b]{2}{*}{ Variabel } & \multicolumn{2}{|c|}{ Kejadian ISPA } & \multirow[b]{2}{*}{ p value } & \multirow[b]{2}{*}{ OR 95\% CI } \\
\hline & ISPA & $\begin{array}{l}\text { Tidak } \\
\text { ISPA }\end{array}$ & & \\
\hline \multicolumn{5}{|l|}{ Penggunaan Obat Anti Nyamuk } \\
\hline $\begin{array}{l}\text { Ada } \\
\text { Tidak Ada }\end{array}$ & $\begin{array}{l}31(73,8 \%) \\
25(48,1 \%)\end{array}$ & $\begin{array}{r}11(26,2 \%) \\
27(51,9 \%)\end{array}$ & 0,021 & $3,044(1,266-7,316)$ \\
\hline Perokok Dalam Rumah & & & & \\
\hline $\begin{array}{l}\text { Ada } \\
\text { Tidak Ada }\end{array}$ & $\begin{array}{l}35(70,0 \%) \\
21(47,7 \%)\end{array}$ & $\begin{array}{l}15(30,0 \%) \\
23(52,3 \%)\end{array}$ & 0,047 & $2,556(1,097-5,956$ \\
\hline Ventilasi & & & & \\
\hline $\begin{array}{l}\text { Tidak Memenuhi Syarat (TMS) } \\
\text { Memenuhi Syarat (MS) }\end{array}$ & $\begin{array}{l}31(79,5 \%) \\
25(45,5 \%)\end{array}$ & $\begin{array}{r}8(20,5 \%) \\
30(54,5 \%)\end{array}$ & 0,002 & $4,650(1,814-11,918$ \\
\hline \multicolumn{5}{|l|}{ Umur } \\
\hline $\begin{array}{l}\leq 28 \text { bulan } \\
>28 \text { bulan }\end{array}$ & $\begin{array}{l}29(58,0 \%) \\
27(61,4 \%)\end{array}$ & $\begin{array}{l}21(42,0 \%) \\
17(38,6 \%)\end{array}$ & 0,904 & $0,869(0,380-1,988)$ \\
\hline Status Gizi & & & & \\
\hline $\begin{array}{l}\text { Gizi Kurang } \\
\text { Gizi Baik }\end{array}$ & $\begin{array}{l}33(75,0 \%) \\
23(46,0 \%)\end{array}$ & $\begin{array}{l}11(25,0 \%) \\
27(54,0 \%)\end{array}$ & 0,008 & $3,522(1,460-8,493)$ \\
\hline $\begin{array}{l}\text { Status Imunisasi } \\
\text { Tidak Lengkap } \\
\text { Lengkap }\end{array}$ & $\begin{array}{l}30(73,2 \%) \\
26(49,1 \%)\end{array}$ & $\begin{array}{l}11(26,8 \%) \\
27(50,9 \%)\end{array}$ & 0,032 & $2,832(1,179-6,801)$ \\
\hline
\end{tabular}

Tabel 3. Permodelan terakhir uji interaksi Multivariat

\begin{tabular}{lrrrr}
\hline \multicolumn{1}{c}{ Variable } & \multicolumn{1}{c}{$\boldsymbol{\beta}$} & $\boldsymbol{p}$ value & \multicolumn{1}{c}{ OR } & \multicolumn{1}{c}{$\mathbf{9 5 \%}$ CI } \\
\hline Kadar $\mathrm{SO}_{2}$ Dalam Rumah & $-1,254$ & 0,138 & 0,285 & $0,054-1,495$ \\
Ventilasi & 1,535 & 0,002 & 4,641 & $1,745-12,341$ \\
Status Imunisasi & 0,928 & 0,054 & 2,530 & $0,983-6,517$ \\
\hline Constant & 48,611 & & & \\
\hline
\end{tabular}

\section{a. Kadar SO2 Dalam Rumah}

Peraturan Menteri Kesehatan No.1077 tahun 2011 tentang pedoman penyehatan udara dalam ruang rumah menyatakan bahwa kadar SO2 dalam rumah maksimal yang dipersyaratkan adalah 0,1 ppm atau 261,75 $\mu \mathrm{g} / \mathrm{Nm} 3$. Hasil pengukuran 
dalam penelitian ini menunjukkan bahwa udara dalam ruang rumah berada di bawah Baku Mutu Lingkungan (BML) yang diperbolehkan yaitu dengan rata-rata kadar $\mathrm{SO} 2$ dalam rumah 40,28 $\mu \mathrm{g} / \mathrm{Nm} 3$.

Pembakaran limbah padat dan pembusukan sampah menghasilkan sedikit gas $\mathrm{SO} 2$ karena dipengaruhi oleh faktor cuaca, arah angin serta kelembaban. Meskipun kadar SO2 dalam rumah tidak melebihi nilai baku mutu lingkungan, balita setiap harinya terpapar udara yang mengandung gas SO2 sehingga dapat mengiritasi sistem pernapasan.

Sulfur dioksida merupakan salah satu dari kelompok gas yang sangat reaktif yang dikenal sebagai "oksida belerang". SO2 terkait dengan sejumlah efek buruk pada sistem pernapasan, dan isu-isu lingkungan lainnya. ${ }^{6}$

Tercemarnya udara disekitar tempat pembuangan akhir sampah menyebabkan kesehatan lingkungan terganggu, termasuk kualitas udara dalam rumah yang berada disekitar tempat pembuangan akhir sampah terutama meningkatnya penyakit ISPA. ${ }^{8}$ Hasil penelitian Weli dan Obisesan ${ }^{7}$ mengenai kondisi meteorologi di sekitar TPA dan implikasinya terhadap stagnasi polutan atmosfer di Rumuolumeni, bahwa konsentrasi SO2, CH4, VOC, H2S, dan $\mathrm{NH} 3$ tinggi di lokasi TPA. Jarak dari pusat TPA memengaruhi konsentrasi polutan udara NO2 dan SO2.

Penelitian yang dilakukan oleh Sinaga ${ }^{12}$ bahwa kadar SO2 dalam rumah di sekitar tempat pembuangan akhir sampah (TPA) Namo Bintang berada di bawah nilai ambang batas yang diperbolehkan yaitu 0,1 ppm. Kadar SO2 dalam rumah terendah adalah sebesar 0,06 ppm sedangkan kadar SO2 yang tertinggi adalah sebesar 0,08 ppm dengan rata-rata kadar $\mathrm{SO} 2$ adalah sebesar $0,07 \mathrm{ppm}$. Hal ini disebabkan karena penghasil utama gas SO2 adalah sepertiganya hasil dari pembakaran bahan bakar dan sepertiganya lagi adalah hasil aktivitas gunung berapi sedangkan hasil pembusukan sampah hanya menghasilkan sedikit gas SO2. Selain itu, ada juga faktor lain yang mendukung dalam hal menghasilkan gas SO2 dalam rumah yaitu perilaku merokok dalam ruang rumah dan penggunaan bahan bakar berupa kayu untuk memasak.

Penelitian ini sejalan dengan Widowati $^{9}$ mengatakan bahwa tingkat konsentrasi SO2 di Kecamatan Taman Sari selalu mengalami peningkatan dan penurunan secara fluktuatif tahun 2006-2013. Hasil analisis menunjukkan bahwa ada hubungan antara tingkat konsentrasi SO2 dengan $8,2 \%$ jumlah kasus ISPA. Penelitian yang sama dilakukan di India oleh Kumar et.al ${ }^{10}$ bahwa tingkat $\mathrm{SO} 2$ dalam ruangan lebih tinggi yang berasal dari bahan bakar biomassa (batubara, kayu, dan minyak tanah) untuk memasak dibandingkan dengan keluarga yang memasak menggunakan gas. Bahan bakar biomassa meningkatkan konsentrasi polutan udara dalam ruangan yang menyebabkan asma, rhinitis dan infeksi saluran pernapasan atas.

\section{b. Penggunaan Obat Anti Nyamuk}

Penggunaan obat nyamuk sebagai alat untuk menghindari gigitan nyamuk dapat menyebabkan iritasi pada saluran pernapasan karena menghasilkan asap dan bau yang tidak sedap. Adanya pencemaran udara di lingkungan rumah akan merusak mekanisme pertahanan paru-paru sehingga mempermudah timbulnya gangguan pernapasan. $^{11}$

Pemberantasan nyamuk dalam rumah sebagian keluarga menggunakan bahan insektisida berupa obat nyamuk semprot dan obat nyamuk bakar. Obat nyamuk bakar biasanya digunakan untuk mengendalikan nyamuk dari dalam rumah tetapi disisi lain asap obat nyamuk dapat menjadi sumber pencemaran udara dalam rumah yang sangat membahayakan kesehatan yaitu gangguan saluran pernapasan karena obat nyamuk jika dibakar mengandung bahan octachloroprophyl ether dapat mengeluarkan bischlorometyl ether atau BCME yang walaupun dalam kondisi rendah dapat menyebabkan batuk, iritasi hidung, tenggorokan bengkak, dan perdarahan. ${ }^{12}$ Berdasarkan laporan hasil penelitian dan pemetaan status kerentanan Aedes aegypti terhadap insektisida di Indonesia tahun 2015 bahwa bahan aktif pestisida di kota Bukittinggi yang digunakan selama 3 tahun terakhir terdiri dari D-aletrin, imiprotrin, metoflutrin, praletrin, siflutrin, dan transflutrin.

Penelitian serupa juga dilakukan oleh Marlina $^{13}$ bahwa proporsi ISPA tertinggi yang memakai obat nyamuk bakar yaitu $96,2 \%$, dan yang terendah tidak memakai obat nyamuk bakar yaitu $48,6 \%$, sedangkan proporsi tidak ISPA tertinggi yang tidak memakai obat nyamuk bakar yaitu $51,4 \%$ dan terendah yang memakai obat nyamuk bakar yaitu 3,8\%. Ada hubungan yang bermakna antara pemakaian obat nyamuk bakar dengan ISPA pada anak balita di wilayah kerja puskesmas Panyabungan Jae Kabupaten Mandailing Natal.

\section{c. Perokok Dalam Rumah}

Penelitian ini sesuai dengan penelitian Mahalastri ${ }^{14}$ mengatakan bahwa pada 60 rumah, $83,33 \%$ diantaranya atau sebanyak 50 rumah terdapat anggota keluarga yang merokok. Sisanya yaitu sebesar $16,67 \%$ atau sebanyak 10 rumah tidak terdapat anggota keluarga yang merokok. Diketahui bahwa paparan asap rokok dalam rumah berhubungan dengan kejadian pneumonia balita. Selain itu juga diketahui bahwa balita yang tinggal di rumah yang terdapat paparan asap rokok dalam rumah mempunyai risiko 4,00 kali lebih besar untuk terkena pneumonia balita dibandingkan 
dengan balita yang tinggal di rumah tanpa paparan asap rokok.

\section{d. Ventilasi}

Menurut Kepmenkes No. 829/Menkes/SK/VII/1999 tentang ketentuan persyaratan kesehatan rumah tinggal secara umum penilaian ventilasi rumah dapat dilakukan dengan cara melihat indikator penghawaan rumah, luas ventilasi yang memenuhi syarat kesehatan adalah lebih dari sama dengan $10 \%$ dari luas lantai rumah dan luas ventilasi yang tidak memenuhi syarat kesehatan adalah kurang dari 10\% dari luas lantai rumah. Pengaruh buruk berkurangnya ventilasi adalah berkurangnya kadar oksigen, bertambahnya kadar gas $\mathrm{CO} 2$, adanya bau pengap, suhu udara ruangan naik, dan kelembaban udara ruangan bertambah.

Hasil penelitian Dewi $\mathrm{dkk}^{15}$ diperoleh dari 53 responden ventilasi yang memenuhi syarat terdapat 42 responden $(45,65 \%)$ dengan tidak ada kejadian ISPA, dari 39 responden dengan ventilasi tidak memenuhi syarat terdapat 37 orang $(40,21 \%)$ mengalami ISPA. Hal ini berarti kondisi sanitasi rumah pada ventilasi ruang tidur menunjukkan adanya kecenderungan data bahwa semakin tidak memenuhi syarat ventilasi maka kejadian ISPA lebih tinggi. Hasil ini menunjukkan secara statistik ada hubungan yang signifikan ventilasi ruang tidur dengan kejadian ISPA di wilayah kerja Puskesmas IV Denpasar Selatan.

\section{e. Umur}

Insiden penyakit pernapasan oleh virus melonjak pada bayi dan usia dini pada anak-anak. ISPA pada umumnya infeksi pertama yang menyerang bayi dan balita selain itu kekebalan tubuh yang dialami oleh bayi dan balita belum terbentuk sempurna. Usia anak dengan usia kurang dari 6 tahun belum memiliki imunitas yang sempurna sehingga sangat mudah terserang penyakit infeksi. ${ }^{16}$

Penelitian berbeda dilakukan oleh Agrina $^{3}$ bahwa hasil analisis pengaruh antara usia anak dengan kejadian ISPA diperoleh hasil bahwa usia bayi lebih cenderung tidak mengalami ISPA dibandingkan usia balita. Hasil uji statistik diperoleh nilai $\mathrm{p}$ value $=0,014$ dengan $\mathrm{OR}=2,160$ maka dapat disimpulkan bahwa ada pengaruh secara bermakna antara usia dengan kejadian ISPA. Usia balita lebih beresiko 2,1 kali terkena ISPA dibandingkan usia bayi. Angka kesakitan dan kematian akibat penyakit ISPA masih tingginya terutama pada bayi dan balita.

\section{f. Status Gizi}

Penelitian Mishra $^{17}$ menunjukkan bahwa terdapat hubungan antara status gizi terhadap kejadian ISPA dalam penggunaan bahan bakar biomassa.

\section{g. Status Imunisasi}

Imunisasi adalah suatu cara untuk meningkatkan kekebalan seseorang secara aktif terhadap suatu antigen, sehingga bila kelak ia terpajan pada antigen yang serupa, tidak terjadi penyakit. Dilihat dari cara timbulnya maka terdapat dua jenis kekebalan, yaitu kekebalan pasif dan kekebalan aktif. Kekebalan pasif adalah kekebaan yang diperoleh dari luar tubuh, bukan dibuat oleh individu itu sendiri. Kekebalan aktif adalah kekebalan yang dibuat oleh tubuh sendiri akibat terpajan pada antigen seperti imunisasi, atau terpajan secara alamiah. Kekebalan aktif biasanya berlangsung lebih lama karena adanya memori imunolgik. $^{18}$

Penelitian Biradar et.al ${ }^{19}$ bahwa anak yang diimunisasi sebagian dan tidak imunisasi lebih rentan untuk mendapatkan penyakit menular, karena vaksin merupakan zat kekebalan biologis yang dirancang untuk menghasilkan perlindungan khusus terhadap penyakit tertentu, merangsang produksi antibodi pelindung dan mekanisme kekebalan tubuh lainnya. Dalam penelitian ini, kurangnya informasi dan motivasi yang menyebabkan sejumlah besar anak-anak putus dari jadwal imunisasi.

\section{SIMPULAN}

Period prevalence kejadian ISPA pada balita di sekitar tempat pembuangan akhir sampah Sukawinatan sebesar 59,6\%. Kondisi udara dalam rumah keluarga balita yaitu rata-rata kadar SO2 dalam rumah 40,28 $\mu \mathrm{g} / \mathrm{Nm} 3$ dan rata- rata kadar SO2 luar rumah $86,33 \mu \mathrm{g} / \mathrm{Nm} 3$; keluarga balita yang menggunakan obat anti nyamuk sebesar $44,7 \%$; perokok dalam rumah keluarga balita sebesar $53,2 \%$; serta balita yang tinggal dengan ventilasi tidak memenuhi syarat sebesar $41,5 \%$. Karakteristik balita yaitu balita yang berumur $\leq 28$ bulan sebesar $53,2 \%$; balita dengan status gizi kurang sebesar $46,8 \%$; serta balita yang imunisasi lengkap sebesar 43,6\%. Variabel penggunaan obat anti nyamuk, perokok dalam rumah, ventilasi, status gizi dan status imunisasi secara statistik menunjukkan adanya hubungan yang bermakna terhadap kejadian ISPA pada balita. Variabel kadar SO2 dalam rumah dan umur balita secara statistik tidak menunjukkan adanya hubungan yang bermakna terhadap kejadian ISPA pada balita. Variabel ventilasi merupakan variabel yang paling dominan berhubungan dengan kejadian ISPA pada balita dengan $\mathrm{OR}=4,641$.

\section{DAFTAR PUSTAKA}

1. World Health Organization. Pencegahan dan pengendalian infeksi saluran pernapasan akut (ISPA) yang cenderung menjadi epidemi dan pandemi di fasilitas pelayanan kesehatan. Geneva: WHO, 2007. 6p.

2. Rudan I, Bosschi-Pinti C, Biloglav Z, Mulholland K, Campbell H. Epidemiology and 
etiology of childhood pneumonia. Bulletin of the World Health Organization. 2008; 86 (5): 40816.

3. Agrina, Suyatno, Arneliwati. Analisa Aspek Balita Terhadap Kejadian Infeksi Saluran Pernafasan Akut (ISPA) di Rumah. Jurnal Keperawatan. 2014; 5 (2): 115-120.

4. Ditjen PP \& PL. Rencana Aksi Program Pengendalian Penyakit dan Penyehatan Lingkungan Tahun 2015-2019. Jakarta: Ditjen PP \& PL, 2018. 15p.

5. Kemenkes RI. Pedoman Pengendalian Infeksi Saluran Pernafasan Akut. Jakarta: Kemenkes RI, 2011. 1p.

6. Roy P, Arghya S. SO2 Emission Control and Finding a Way Out to Produce Sulphuric Acid from Industrial SO2 Emission. Journal Chemical Engineering \& Process Technology. 2015, 6 (2): $1-7$.

7. Weli VE, Obisesan. Meteorological Conditions in the Vicinity of Landfill and its Implications for Atmospheric Pollutant Stagnation in Rumuolumeni, Port Harcourt, Nigeria. Journal of Natural Sciences Research. 2014; 4 (15): 22243186.

8. Sinaga SDP, Hasan W, Dharma S. Hubungan Antara Komponen Rumah dan Jarak Rumah Terhadap Kadar SO2 Dalam Rumah di Sekitar Tempat Pembuangan Akhir Sampah (TPA) Namo Bintang Kecamatan Pancur Batu Kabupaten Deli Serdang. Jurnal USU Lingkungan dan Kesehatan Kerja. 02 Januari 2013; 2 (1): 1-9.

9. Widowati R, Haryanto B. Hubungan Antara Tingkat Konsentrasi NO2, SO2, dan PM10 di Udara Ambient Dengan Kejadian ISPA Penduduk Kecamatan Taman Sari Jakarta Barat 2006-2013. Depok: Fakultas Kesehatan Masyarakat Universitas Indonesia, 2014. 10p.

10. Kumar R, Nagar JK, Raj N, Kumar P. Impact of Domestic Air Pollution from Cooking Fuel on Respiratory Allergies in Children in India. Asian
Pacific Journal of Allergy and Immunology. 2008 December 01; 26(4): 213-22.

11. Chahaya IS, Nurmaini. Faktor-Faktor Kesehatan Lingkungan Perumahan Yang Mempengaruhi Kejadian ISPA Pada Balita di Perumahan Nasional. Majalah Kedokteran Nusantara. 3 Maret 2005; 38 (3): 1-5.

12. Depkes RI. Pedoman Pemberantasan Penyakit Infeksi Saluran Pernafasan Akut Untuk Penanggulangan Pneumonia Pada Balita. Jakarta: Depkes RI, 2002.1p.

13. Marlina L, Sarumpaet SM, Rasmilah. FaktorFaktor Yang Berhubungan Dengan Kejadian Infeksi Saluran Pernafasan Akut (ISPA) Pada Anak Balita di Puskesmas Panyabunganjae Kabupaten Mandailing Natal 2014. Jurnal USU Gizi, Kesehatan Reproduksi, dan Epidemiologi. 5 Mei 2015; 1 (1): 1-9.

14. Mahalastri NND. Hubungan Antara Pencemaran Udara Dalam Ruang Dengan Kejadian Pneumonia Balita. Jurnal Berkala Epidemiologi. 3 September 2014; 2 (3): 392-403.

15. Dewi PS, Darmadi IGW, Marwati NM. Hubungan Faktor-faktor Sanitasi Rumah dengan Kejadian ISPA di Wilayah Kerja Puskesmas IV Denpasar Selatan Tahun 2014. Jurnal Kesehatan Lingkungan 01 November 2014; 4 (2): 175-180.

16. Meadow R, Simon J. Lecture Notes: Pediatrika Edisi 7. Jakarta: Erlangga Medical Science, 2005. 233p.

17. Mishra V. Indoor air pollution from biomass combustion and acute respiratory illness in preschool age children in Zimbabwe. Int $\mathrm{J}$ Epidemiol. 2003 October 01; 32 (5): 847-53.

18. IDAI (Ikatan Dokter Anak Indonesia). Buku Imunisasi di Indonesia. Jakarta: Satgas Imunisasi, 2001. 1p.

19. Biradar, Mallikarjun K. et.al. Immunization Status and Occurrence of Acute Respiratory Infection in Under Five Children. Journal of Advanced Scientific Research. 2014; 5(3): 31-33. 